\title{
The Riss-Würm interglacial from West to East in the Alps: an overview of the vegetational succession and climatic development
}

\author{
Ruth Drescher-Schneider ${ }^{1}$ \\ 1 Schaftal 154, A - 8010 Kainbach/Schillingsdorf, Austria
}

Received: 7 April 1999; accepted in revised form: 17 April 2000

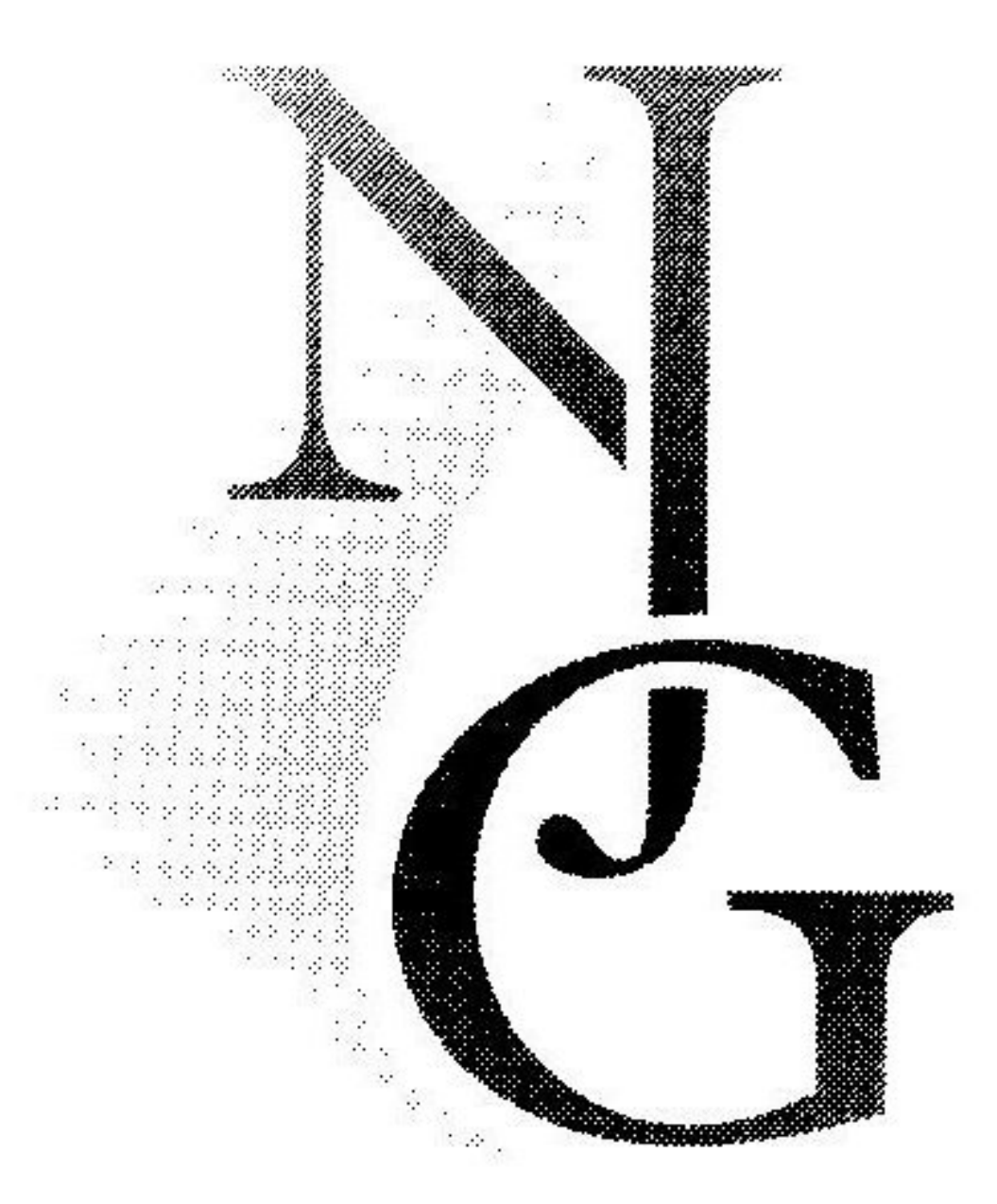

\begin{abstract}
The vegetational and climatic developments during the Riss-Würm interglacial in the area on the northern flank of the Alps are reviewed. Reforestation seems to have begun over the whole region with a dwarf-shrub and ensuing shrub phase, leading to birch and/or pine woodland. The rise in summer temperatures, which $\delta^{18} \mathrm{O}$ values suggest to have been a two-stage event, permitted the immigration and expansion of more demanding trees (elm, oak, lime, ash, ivy, hazel, yew, etc.). Following the thermal maximum, which took place during the hazel and yew biozones, hornbeam dominated the forests in the alpine foreland, whilst fir/spruce forests formed the dominant vegetation at sites closer to the Alps or at a higher altitude. A marked climatic deterioration can only be recognised towards the end of the interglacial, which led to extensive spruce/pine and, finally, almost pure pine forests.
\end{abstract}

Keywords: alpine foreland, climatic development, Eemian, Riss-Würm interglacial, vegetational succession

\section{Introduction}

Summaries of vegetational successions during the Riss-Würm interglacial have already been published by several authors (among them Wegmüller, 1992; Grüger, 1979). Thanks to the considerable number of well developed pollen diagrams available from sites ranging across the Alps from West to East, it is now possible to construct a differentiated picture of the interglacial vegetation corresponding to the different types of landscape and climate. Since one of the key sequences from the Eastern Alps - that from Mondsee - has been recently re-investigated, it seems appropriate to present here an updated overview of the vegetational and climatic successions of the RissWürm interglacial.

The results from the majority of well-investigated and published sites with complete interglacial se- quences (Fig. 1) have been taken into account here. Only those sequences were used for the tabulated comparison of vegetational successions (Table 1), however, that showed a virtually complete Riss-Würm succession without major hiatuses, and that are located at sites where the overlying sediments held evidence of at least one -if not two - early Würm interstadials, or - where alternatively - the age of the deposits was absolutely clear from their geological situation. The first Würm interstadial is divided into two phases by a short, sharp interval of climatic deterioration. (Montaigu oscillation, according to Woillard, 1978). This feature, characterising this interstadial and recognisable right across the area from West to East in the Alps, should serve to quell those doubts, still often expressed, as to whether this interstadial horizon - and by implication its underlying interglacial sequence are truly coeval at the sites under consideration. 


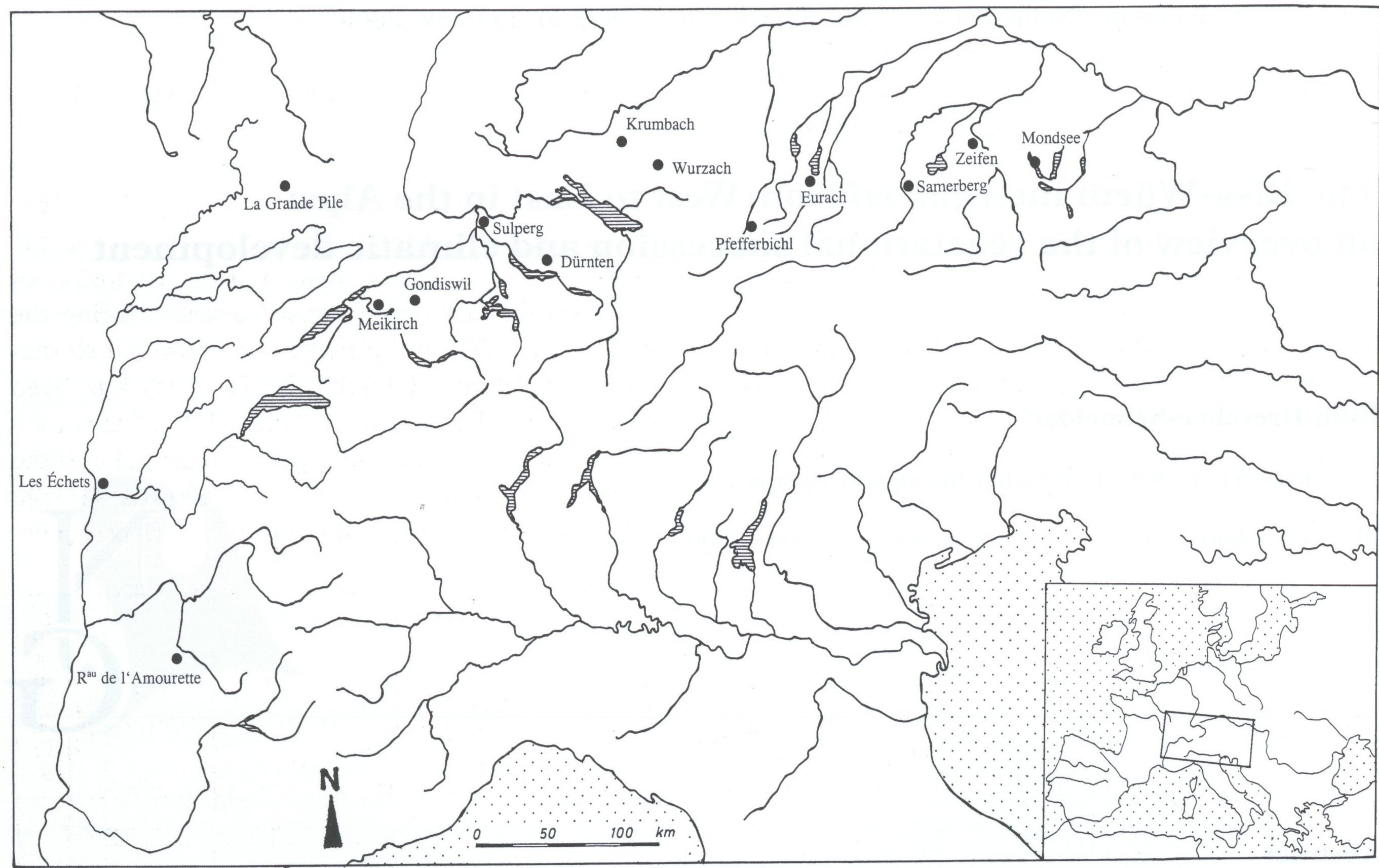

Fig. 1. Geographical distribution of sites with Riss-Würm pollen diagrams mentioned in the text.

For comparison of the vegetation successions in individual regions, local pollen assemblage zones (LPAZ) were used, as has become customary for the description of the Late Würm and Holocene vegetational history (cf. Berglund \& Ralska-Jasiewiczowa, 1986). To this effect, the dominant taxon is placed first and in bold in the tabular comparisons, the others following in order of abundance. Where a taxon occurs in low-percentage values only but possesses a particular significance, it is indicated in italics.

Since, so far, virtually no absolute dating is avail- able for the Riss-Würm interglacial, we know very little about the duration of individual pollen zones and consequently about the real relationships in time between closely similar zones at separate sites. For the end of the interglacial, annually laminated sediments have been observed at Krumbach (Frenzel \& Bludau, 1987). The conclusion there was that the duration from the end of the hornbeam/hazel zone (Carpinus/Corylus zone) to the end of the interglacial was at least 3000, perhaps even 4000 years. This agrees well with the estimates made by Müller (1974)

Table 1. A comparison of vegetational successions from Les Echets, Grande Pile, Meikirch, Gondiswil, Samerberg and Mondsee, in terms of local pollen zones and their dominant or characteristic plant taxa.

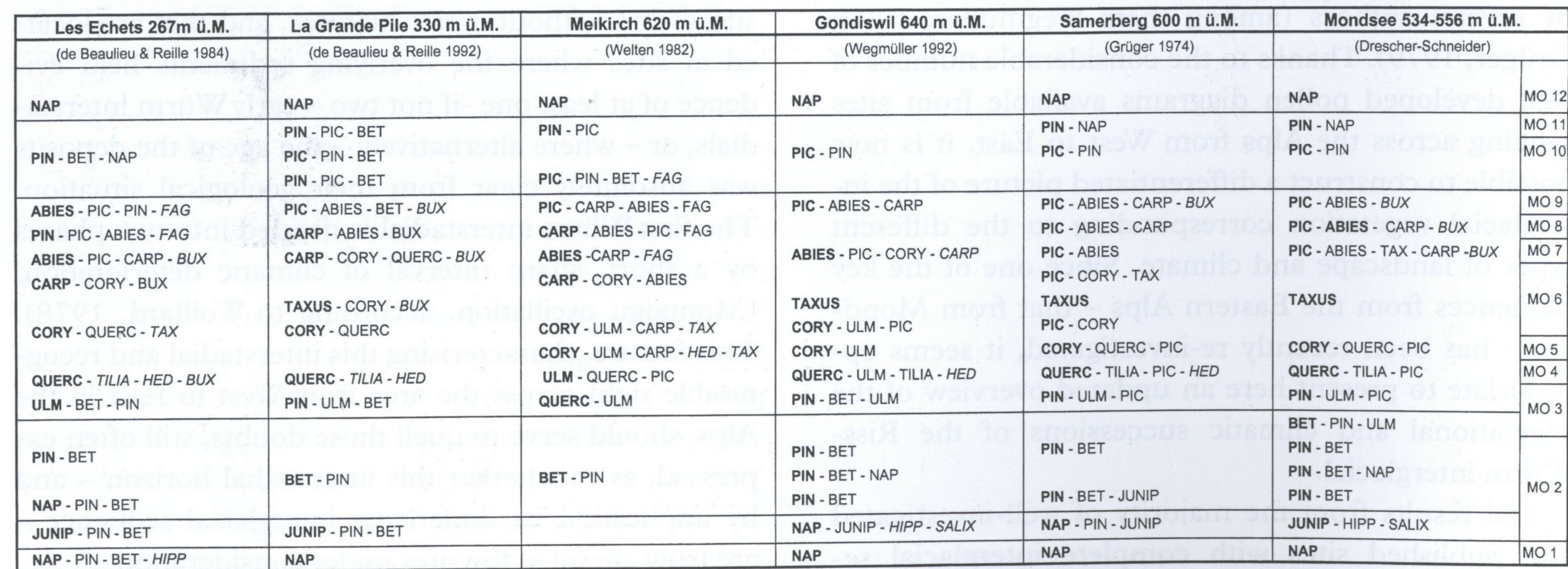


from laminated interglacial sediments at Bispingen in northern Germany. The Carpinus/Corylus zone is not developed in a comparable way in all diagrams, however, so that these figures can be applied in some cases only as approximations.

The $\delta^{18} \mathrm{O}$ investigations at Mondsee (to be detailed further on) have indicated that an important rise in temperature took place at the beginning of the birch/pine/spruce (Betula/Pinus/Picea) phase, the uppermost part of LPAZ 2 (Fig. 2). The expansion of elm commenced as a response to this warming. We assume on the basis of this evidence that it is highly probably that the elm expansion took place at more or less the same time along the northern margin of the Alps.

\section{The vegetational succession}

The vegetational succession from the late Riss to the elm rise

The return of the forest at the beginning of the RissWürm interglacial proceeded in a similar way as the return known from the Late Würm. Expansion of dwarf shrubs can be recognised already during the treeless zone. Willows (Salix) can be found in all diagrams, whilst dwarf birch (Betula nana) has been identified up till now only at Zeifen (PZ 1, Jung et al., 1972) and at Mondsee (Oeggl, pers. comm.) and the green alder (Alnus viridis) only at Mondsee (Oeggl, pers. comm.). The expansion of sea buckthorn (Hip-

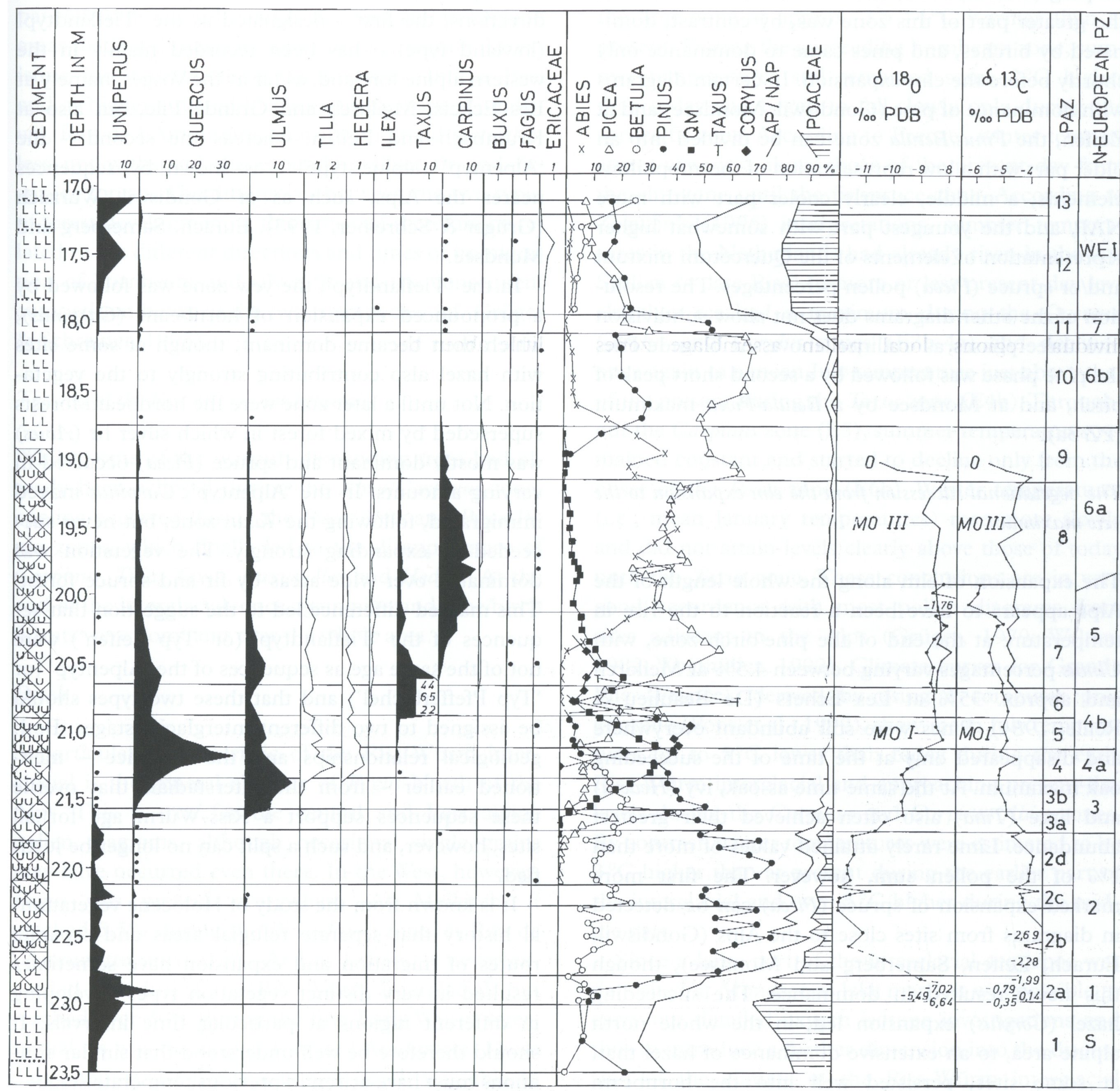

Fig. 2. Simplified pollen diagram from Mondsee together with $\delta^{18} \mathrm{O}$ und $\delta^{13} \mathrm{C}$ isotope curves, as climatic indicators. 
pophae rhamnoides) also took place in certain sequences during this zone, but in others it occurred only in the following shrub zone (i.e. more or less at the same time as the more pronounced but shorter expansion of juniper (Funiperus).

The first regional differentiation appeared in the succeeding pine/birch zone. In those diagrams showing a stronger montane influence, such as those from Gondiswil (PZ 2b and 3: Wegmüller, 1992), Samerberg (PZ 2: Grüger, 1979), Eurach (PZ 2: Beug, 1979) and Mondsee (PZ 2b-2d: Drescher-Schneider, in prep.), this zone was dominated by pine. In diagrams characteristic of the alpine foreland, such as those from Meikirch (Welten, 1982), Grande Pile (Woillard, 1978; De Beaulieu \& Reille, 1992), Sulperg (Welten, 1982) and Dürnten (Welten, 1982), the greater part of this zone was, by contrast, dominated by birches, and pines came to dominance only shortly before the elm expansion. In certain diagrams with dominance of pine (Gondiswil, Mondsee) and at Zeifen, the Pinus/Betula zone can be divided into an older part with a low representation of thermophilous elements, a middle, clearly cooler part with more NAP, and the youngest part with somewhat higher representation of elements of the Quercetum mixtum and/or spruce (Picea) pollen percentages. The resolution of the other diagrams does not allow subdivision into three phases as outlined above. At Grande Pile, the pine phase was followed by a second short peak of birch, and at Mondsee by a Betula/Picea maximum (PZ 3a).

The vegetational succession from the elm expansion to the yew maximum

The expansion of elm along the whole length of the Alps appears to have been a reaction to the rise in temperature at the end of the pine/birch zone, with Ulmus percentages varying between $4.5 \%$ at Meikirch and approx. $35 \%$ at Les Echets (De Beaulieu \& Reille, 1984). Pines were still abundant everywhere and disappeared only at the time of the succeeding oak maximum. At the same time as oak, ivy (Hedera) and lime (Tilia) also often achieved their greatest abundance. Lime rarely attained values of more than $1 \%$ of the pollen sum, however. The first more marked expansion of spruce (Picea) can be detected in diagrams from sites close to the Alps (Gondiswil, Eurach, Zeifen, Samerberg and Mondsee), though this never resulted in dominance. The succeeding hazel (Corylus) expansion led, in the whole north alpine area, to an extensive dominance of hazel that, at some sites, persisted well into the hornbeam (Carpinus) zone. The Corylus zone was brought to an end by a generally very marked expansion of yew (Taxus). Only at Les Echets $(<1 \%)$ and at Meikirch (maximum $4.8 \%$ ) is a clear Taxus zone absent. At Grande Pile and at Gondiswil, the Taxus curve is clearly two-peaked. Percentage values average over $40 \%$ and reach maximum values of approx. $80 \%$ at Zeifen.

\section{The middle part of the interglacial}

Up to the time of the Taxus maximum, the vegetational development proceeded to a large extent in a similar way, with just minor differences, at all the sites investigated. In the middle part of the interglacial, regional differences became very much more apparent. The vegetation seems to have developed into two main directions; the first - designated as the 'Tieflandtyp' (lowland type) - has been recorded mainly in the western alpine foreland, as far as the Vosges, namely at Les Echets, Meikirch and Grande Pile, but also at Krumbach and Zeifen, whereas the second - the 'Alpentyp' (alpine type) - is shown by sequences nearer the Alps, such as at Gondiswil, Wurzach (Grüger \& Schreiner, 1993), Eurach, Samerberg and Mondsee.

In the 'Tieflandtyp', the yew zone was followed by a pronounced expansion of hornbeam (Carpinus), which then became dominant, though at some sites with hazel also contributing strongly to the vegetation. Not until a later zone were the hornbeam forests superseded by mixed forest in which silver fir (Abies) was mostly dominant and spruce (Picea) occurred in varying amounts. In the 'Alpentyp', Carpinus indeed immigrated, following the Taxus zone, but never succeeded in expanding strongly. The vegetation was dominated over wide areas by fir and spruce forest. This marked difference led to the suggestion that sequences of the 'Tieflandtyp' (or 'Typ Zeifen') were not of the same age as sequences of the 'Alpentyp' (or 'Typ Pfefferbichel') and that these two types should be assigned to two different interglacial stages. Both geological relationships and the evidence - mentioned earlier - from the interstadials that overlie these sequences support a Riss-Würm age for all sites, however, and such a split can no longer be justified.

It is known from the study of Holocene vegetational history that separate refugial areas and separate routes of migration and expansion have sometimes resulted in very distinct vegetation types developing in different regions at particular time intervals. It should therefore be well understood that similar situations must have arisen in previous temperate stages.

Comparison of the pollen sequences from Mond- 
see and Les Echets makes clear that the immigration - and likewise the expansion - of spruce occurred progressively later at localities to the west. Likewise localities at lesser altitudes and greater distances from the Alps also show a delayed spruce expansion. It must therefore be deduced that spruce immigrated from the East and South-East. The relatively early immigration of spruce in the pollen diagram from Rau de l'Amourette (Gremmen et al., 1984), comparable to those at Samerberg and Mondsee, might suggest immigration from the south over the alpine passes, however, just as has been demonstrated for the Holocene. The direction of immigration of silver fir cannot yet be clearly recognised from the existing data.

In contrast to spruce, the indications are that hornbeam immigrated from the South-West. Its early expansion and establishment in the West and in lowland areas made it difficult for silver fir to penetrate the existing forest vegetational communities. In the East and at higher situated localities in the west (Gondiswil, Rau de l'Amourette), hornbeam could nevertheless not withstand the expanding silver fir and firspruce forests. The differences between the two types of forest development at this time can therefore be related to the different directions and times of immigration of hornbeam and silver fir and the consequent competition between the two tree species (cf. Grüger \& Schreiner, 1993).

\section{The end of the Riss-Würm interglacial}

Whilst some of the warmth-demanding trees had already been eclipsed during the Abies/Carpinus zone, cooling occurred during the Picea/Abies and Picea/Pinus zones, which finally led to the disappearance of Carpinus, Tilia, Taxus, Buxus, Ilex and Hedera. At the end of the interglacial, once again pine and pine/birch forests were dominant over the whole area.

\section{Beech}

A particular characteristic of the Riss-Würm interglacial is the general absence of Fagus North of the Alps. This is true for the central and East alpine pollen diagrams, although occasional single grains may have occurred even there. In the West, however, Fagus was present everywhere. At Meikirch, it reached 5.5\% during the Picea-Pinus zone, at Rau de l'Amourette up to $12 \%$. At Les Echets, it never exceeded $1 \%$ during the Riss-Würm interglacial, but reached over 30\% during the first Early Würm interstadial, as was the case at Rau de l'Amourette. These data support the hypothesis that beech was able to migrate from the Italian Western Alps through the Val di Susa into the region of Briançon and Grenoble and eventually expanded along the Alps right into Westcentral Switzerland. Evidence that beech was abundantly present on the southern side of the Alps can now be confirmed from a dated pollen diagram from Kärnten (Carinthia, Austria) (Draxler, in prep.).

\section{The development of climate}

Ideas about the course of climatic change during the Würm and Eemian are based principally on interpretation of indicator plants (Frenzel, 1991; Zagwijn, 1996). Frenzel concludes that summer temperatures in central Europe must have been $1-1.5^{\circ} \mathrm{C}$ higher during the oak-elm zone than today, rose further during the hazel zone and reached a maximum during the lime zone at approx. $3.5-4^{\circ} \mathrm{C}$ warmer than at present. During the succeeding hornbeam zone, summer temperatures still remained some $2^{\circ} \mathrm{C}$ higher than today and began to fall slowly only during the spruce/fir zone. According to Frenzel, winter temperatures were just above those of the present day from the elm zone until the fir/spruce zone. According to Zagwijn's (1996) interpretations, summer temperatures in the Netherlands had already risen in the late Saalian (= late Riss) to more or less present-day levels; they reached a maximum during the Quercus/ Corylus and Corylus zones (E3b-4a) and declined once again to a mean July temperature just above that of the present during the Taxus zone (E4b). Throughout the Carpinus zone (E5), summer temperatures remained constant and started to decline only from the onset of the Picea zone (E6b). Winter temperatures (i.e., mean January temperatures) rose more slowly and did not attain levels clearly above those of today until the Taxus zone. These conclusions are in very good accordance with most pollen diagrams from sites adjacent to the Alps (Grüger, 1979; Welten, 1982; Wegmüller, 1992). Climate curves for Grande Pile (France), derived by using a computer programme (Pons et al., 1992), show mean July temperatures up to $5^{\circ} \mathrm{C}$ lower than today during the early Riss-Würm interglacial and approaching present-day levels during the Carpinus and Carpinus/Abies zones. By contrast, winter temperatures were estimated to be $3^{\circ} \mathrm{C}$ higher than at present during the earlier part of the interglacial and even $5^{\circ} \mathrm{C}$ higher during the middle part.

Since a large part of the interglacial sequence was deposited at Mondsee as lake marls, it was possible to carry out detailed oxygen isotope investigations and thus to introduce a further dimension into the discussion of the climate of the Riss-Würm interglacial (Drescher-Schneider \& Papesch, 1998). 
The return of woodland vegetation at the end of the late Riss showed a similar pattern to that of the Late Würm. A rise in temperature made possible the expansion of pioneer shrubs, Betula nana and Alnus viridis, then funiperus, Hippophae and Salix, followed by expansion of the tree birches and pines. This rise in temperature is not recorded by the oxygen isotope curves. (Fig. 2). The highly variable $\delta^{18} \mathrm{O}$ values and, particularly, the irregular $\delta^{13} \mathrm{C}$ curve reflect the situation that - until nearly the end of LPAZ $2 b$ - the production of biogenic carbonate was so small that the measurements principally relate to allochthonous carbonate. Furthermore, a search of the literature revealed hardly any statements about the scale of this first temperature rise. Only Zagwijn (1996) postulated a summer warming of about $6^{\circ} \mathrm{C}$, that is from $+10^{\circ} \mathrm{C}$ to $+16^{\circ} \mathrm{C}$.

In association with the higher temperature, a higher precipitation rate could well be expected. Zagwijn (1996) does, however, not recognise this until the Taxus zone. On the basis of the oxygen-isotope curves, climatic conditions during the pine zones (LPAZ 2b-2d) at Mondsee seem to have remained more or less constant. The exception to this is LPAZ $2 \mathrm{c}$, where the pollen curves indicate a short deterioration of climate, with a thinning of the pine woodland and an increase in birch and juniper. The $\delta^{13} \mathrm{C}$ curve (Fig. 2) indicates a possible inwash of allochthonous sediment by the Steinerbach stream. The first rise in the $\delta^{18} \mathrm{O}$ curve in LPAZ $3 \mathrm{a}$ is the result of a distinct increase in summer temperatures. The first trees to respond to this warming were pines and birches, followed by elms and oaks. The $\delta^{18} \mathrm{O}$ curve suggests that summer temperatures probably remained constant during the elm zone (LPAZ 3b). To what extent the winter temperature had risen in the meantime is hard to evaluate. It cannot have exceeded present-day values, since pines were still present, contributing over $40 \%$ of the pollen sum, and also represented by macrofossils (Oeggl, pers. comm.), whereas the coldsensitive taxa were only just immigrating (Tilia) or still absent (Hedera, Ilex).

At Mondsee, only Hedera, Ilex, Buxus and Naias amongst those taxa generally used as climatic indicators, are available to help estimate changes in climate for the following interval. Trapa natans, as well as Tilia tomentosa and Acer tartaricum, are absent.

During the course of the Quercus/Tilia/Hedera zone (LPAZ 4), summer temperatures seem, according to the $\delta^{18} \mathrm{O}$ curve, to have risen still further and to have reached their maximum at the beginning of the hazel zone (LPAZ 5). The high pollen percentages of Tilia (partly Tilia platyphyllos according to Oeggl, pers. comm.) and Hedera in these two pollen zones suggest a mean July temperature of about $17^{\circ} \mathrm{C}$ and a January mean of at least $-1.5^{\circ} \mathrm{C}$ (cf. Frenzel, 1991). It can be inferred from the evidence of the oxygen-isotope data that, at least until the end of the hornbeam zone(s) (LPAZ 6-8), summer temperatures remained unchanged, with no major oscillations. Immigration of Ilex in LPAZ 6 was probably made possible by increasing winter temperatures, since holly only flowers when mean January temperatures exceed $-0.5^{\circ} \mathrm{C}$. In LPAZ 7 and 8, i.e. during the hornbeam zones, Buxus can be found fairly regularly (though in relatively small amounts). Box requires, along with summer temperatures of at least $18{ }^{\circ} \mathrm{C}$, a mean January temperature of $0^{\circ} \mathrm{C}$ to $+1^{\circ} \mathrm{C}$. When July temperatures exceed $20^{\circ} \mathrm{C}$, it can also withstand colder winters. During the Abies expansion, both pollen diagrams from Mondsee show an interruption of the Buxus curve. At the same time, the curves of Picea and Corylus show fluctuations, particularly in pollen diagram III. These phenomena may be accounted for by somewhat unstable climatic conditions, for example, an interval with more subcontinental conditions than before or after. The winter temperatures cannot have fallen below a January mean of $-0.5^{\circ} \mathrm{C}$, however, considering that Hedera and Ilex persisted without difficulty. Occurrences of Buxus persisted into LPAZ 9. Thus, a pronounced deterioration of the climate can only be recognised towards the end of the interglacial, at the beginning of the Picea/Pinus zone and particularly during the succeeding Pinus/Picea zone.

\section{Acknowledgements}

Sincere thanks are due to Charles Turner for the translation of this contribution.

\section{References}

Berglund, B.E. \& Ralska-Jasiewiczowa, M., 1986. Handbook of Holocene palaeoecology and palaeohydrology. John Wiley \& Sons (Chichester): $869 \mathrm{pp}$.

Beug, H.-J., 1979. Vegetationsgeschichtlich-pollenanalytische Untersuchungen am Riß/Würm-Interglazial von Eurach am Starnberger See/Obb. Geologia Bavarica 80: 91-106.

De Beaulieu, J.-L. \& Reille, M., 1984. The pollen sequence of Les Echets (France): a new element for the chronology of the upper Pleistocene. Géographie Physique et Quaternaire 38: 3-9.

De Beaulieu, J.-L. \& Reille, M. ,1992. The last climatic cycle at La Grande Pile (Vosges, France). A new pollen profile. Quaternary Science Reviews 11: 431-438.

Drescher-Schneider, R. \& Papesch, W., 1998. A contribution towards the reconstruction of Eemian vegetation and climate in central Europe: first results of pollen and oxygen-isotope investigations from Mondsee, Austria. Vegetation History and Archaeobotany 7: 235-240.

Frenzel, B., 1991. Das Klima des letzten Interglazials in Europa. Paläoklimaforschung 1: 51-78. 
Frenzel, B. \& Bludau, W., 1987. On the duration of the interglacial to glacial transition at the end of the Eemian interglacial (deep sea stage $5 \mathrm{E}$ ): botanical and sedimentological evidence. In: Berger, W.H. \& Labeyrie, L.D. (eds.): Abrupt climatic change. D. Reidel Publishing Company (Dordrecht): 151-162.

Gremmen, W., Hannss, Ch. \& Puissegur, J.J., 1984. Die warmzeitlichen Ablagerungen am Rau de l'Amourette (Trièves, französische Alpen). Eiszeitalter und Gegenwart 34: 87-103.

Grüger, E., 1979. Spätriß, Riß/Würm und Frühwürm am Samerberg in Oberbayern - ein vegetationsgeschichtlicher Beitrag zur Gliederung des Jungpleistozäns. Geologia Bavarica 80: 5-64.

Grüger, E. \& Schreiner, A. 1993. Riß/Würm und würmzeitliche Ablagerungen im Wurzacher Becken (Rheingletschergebiet). Neues Jahrbuch für Geologie und Paläontologie Abhandlungen 189: 81-117.

Jung, W., Beug, H.-J. \& Dehm, R., 1972. Das Riß/Würm-Interglazial von Zeifen, Landkreis Laufen a.d.Salzach. Bayerische Akademie von Wissenschaften, Mathematische und Naturwissenschaftliche Klasse Neue Folge 151: 130 pp.
Müller, H., 1974. Pollenanalytische Untersuchungen und Jahresschichtenzählungen an der eem-zeitlichen Kieselgur von Bispingen/Luhe. Geologisches Jahrbuch A 21: 149-169.

Pons, A., Guiot, J., De Beaulieu, J.-L. \& Reille, M., 1992. Recent contribution to the climatology of the last glacial-interglacial cycle based on French pollen sequences. Quaternary Science Reviews 11: 439-448.

Wegmüller, S., 1992. Vegetationsgeschichtliche und stratigraphische Untersuchungen an Schieferkohlen des nördlichen Alpenvorlandes. Denkschrifte der Schweizerischen Akademie der Naturwissenschaften 102: 82 pp.

Welten, M., 1982. Pollenanalytische Untersuchungen im Jüngeren Quartär des nördlichen Alpenvorlandes der Schweiz. Beiträge zur Geologischen Karte der Schweiz, Neue Folge 156: 174 pp.

Woillard, G.M., 1978. Grande Pile peat bog: a continuous pollen record for the last 140.000 years. Quaternary Research 9: 1-21.

Zagwijn, W.H., 1996. An analysis of Eemian climate in western and central Europe. Quaternary Science Reviews 15: 451-469. 